\title{
Study the effect of replacing the skim milk used in making ice cream with some dried fruit
}

\author{
Ghanim Mahmood HASAN ${ }^{1}$, Ali Mohammed SAADI ${ }^{2 *}$ (D), Mohammed Ahmed JASSIM ${ }^{3}$
}

\begin{abstract}
Ice cream is a popular frozen dairy product over the world, and there are many types of ice cream that differ according to additives and manufactured way, the goal of this research was to prepare skim milk dried fruits powder (banana, quince peach, apples) for ice cream production. The chemical, physical, microbiological and sensory attributes were evaluated for resultant ice cream. As the results indicated there was an increase in the total solids of resultant ice cream, especially when using banana powder because of its high carbohydrate content and low $\mathrm{pH}$ value of all treatments as compared to the control. As well as the specific weight and viscosity, increased in most treatments as compared to the control due to the increase in the rate of total solids . while the yield decreased in all treatments due to the increased viscosity which led to difficulty of air entering to the product. The microbial content of the resultant ice cream was decreased or close to the value of the control for all treatments except for the treatments in which the skim milk was replaced by the dried banana powder, this may be due to the fact that added fruit powder is an additional factor for increasing the number of bacteria as compared with dried skim milk powder, as well as the addition of dried fruits powder result in a slight improvement in flavor. There was an improvement in the appearance of the resultant ice cream in which banana powder was used.
\end{abstract}

Keywords: ice cream; skim milk; banana; peache; quince; apple.

Practical Application: Making ice cream using fruit extracts as a substitute for milk powder.

\section{Introduction}

Ice cream may be defined as a frozen dairy product made by apt blending and processing of cream and other milk products together with sugar, flavor and color, with the incorporation of air, with or without stabilizer during the freezing process (Sukumar, 1980).

Ice cream is both an emulsion and foam, comprised of four structures which are ice crystals, air bubbles, fat globules and aggregates, and the unfrozen serum phase (Clarke, 2005; Goff \& Hartel, 2013).

The dairy market is hugely competitive, with dairy industries always looking for new products to reach the consumer. Projective techniques, such as the Completion task, are great allies in this process, as they identify consumer needs and expectations, which helps in developing brand new, more competitive products (Torres et al., 2020)

It has been found (Karaman et al., 2014) Increase in persimmon puree resulted in a decrease in the dry matter, ash, fat, protein contents, and viscosity of ice cream mix. Glucose, fructose, sucrose, and lactose were determined to be major sugars in the ice cream samples including persimmon and increase in persimmon puree concentration increased the fructose and glucose content. Better melting properties and textural characteristics were observed for the samples with the addition of persimmon. Magnesium, $\mathrm{K}$, and $\mathrm{Ca}$ were determined to be major minerals in the samples and only $\mathrm{K}$ concentration increased with the increase in persimmon content.

From time to time, population's demands develop and healthy products consumption is increasing. Thus, the food industry develops and marks food with added bioactive components, named "functional foods" that not only deliver basic nutrients, but also provide health benefits (Villalva et al., 2017)

Ice cream is a pasteurized, homogenized, frozen food product characterized by a complex matrix that contains proteins, fat, air, minerals, additives, and sweeteners (Ozdemir et al., 2008).

In a study done The effect of the Lactobacillus casei 01 and inulin addition on sheep milk ice cream during storage $\left(-18{ }^{\circ} \mathrm{C}, 150\right.$ days) L. casei 01 addition produced several volatile compounds, such as carboxylic acids, alcohols, aldehydes and ketones. Also, scanning electron microscopy showed an interaction between probiotic bacteria and inulin fibre on synbiotic ice cream and the adhesion of L. casei to Caco- 2 cells was observed (Balthazar et al., 2018)

whereas the commercial ice cream available is generally poor in natural antioxidants like vitamin C, natural pigments, and polyphenols. Practically, the possibility to improve the nutritional value of ice cream using ingredients with health benefits is valuable, focusing on natural antioxidants, natural 
pigments, vitamins, low fat and free from synthetic additives such as fruit and vegetables (Sun-Waterhouse, 2011).

whereas there is a study Grape juice residue was incorporated into ice cream at $2.5 \%, 5.0 \%$ and $10.0 \%$ to obtain a product with functional characteristics. Where Ice creams containing grape juice residue had a higher concentration of phenolic compounds and antioxidant activity compared to the control samples (Vital et al., 2018).

The ice-cream matrix might be a good vehicle for probiotic cultures, due to its composition, which includes milk proteins, fat and lactose, as well as other compounds. Moreover, the fact that it is a frozen product and the high $\mathrm{pH}$ values (5.5 to 6.5) certainly contributes to the survival of the beneficial cultures (Cruz et al., 2009; Ferraz et al., 2012).

The incorporation of prebiotic compounds is also an alternative for functional ice creams (Balthazar et al., 2015).

Ice cream manufactured using a substantial amount of pumpkin pulp (PP) and carrot pulp (CP) has a high organoleptic acceptability. PP and CP were added to typical control ice cream (TC) up to $20 \%$. Through adding PP and CP, natural flavor, unique color, and health-promoting constituents were presented (Hassan \& Barakat, 2018).

Banana ice cream showed firmness, cohesiveness and overall acceptance similar to the commercial product, but lower appearance and texture scores (Januário et al. 2018).

In another study Tagatose, Litesse ultra and polydextrose (as prebiotics) were used in ice cream production and mixtures and these mixtures were inoculated with Bifidobacterium bifidum, Lactobacillus paracasei and Bifidobacterium longum combined culture. Frozen raspberry fruits, commercial raspberry and blackberry fruit purees were used as taste flavor enhancers in synbiotic ice cream, It was determined that frozen fruit and fruit purees addition and using prebiotics significantly affected the Lactobacillus paracasei and Bifidobacterium spp. viability and color, appearance, flavor, taste and overall sensory scores of the synbiotic goat's milk ice creams where Synbiotic ice cream samples maintained their probiotic properties during storage and were generally well appreciated in terms of sensory properties (Acu et al., 2020).

The research of the Food Research Foundation in Britain that the composition of the apple fruit is $80 \%$ water, sugars $10 \%$ and $4 \%$ of vitamins and minerals, and the rest of fiber and other substances. They are given 50 to 80 calories or calories, depending on their sweetness. Removing the crust and heart of the apple, as many do, deprives humans of eating 50\% of their content of vitamin $\mathrm{C}$ and fiber, while not affected by the amount of sugars, Apples also contain high amounts of antioxidants. The concentration of these substances differs in its outer shell from that of its white core. The abundance of fiber, especially pectin, which reduces the intestinal absorption of cholesterol and sugars, and regulates the natural passage within the intestines, and also rid the body of mineral toxins such as mercury or lead.

While bananas are rich in antioxidants that protect against cancer and heart disease, the banana strengthens the lining of the stomach and intestines and protects them from hyperacidity,
Quince is rich in pectin, gum, tannins and flavones It is considered an important antioxidant in addition to its use in the treatment of many cases, including laryngitis and its effectiveness in the treatment of respiratory infections, the Peaches is important in the treatment of constipation and dysuria in pregnant women, constipation and delayed menstruation and stimulate blood flow in the body (Al-Rubaie, 2013).

In a study use some plants it was used the UFP ora-pro-nóbis, In the ice cream industry a plant that is gaining attention in recent years, The results revealed that the best known UFP species were taro and roselle, followed by ora-pro-nóbis and lamb's ear. In the WA test, ice cream was described mainly in the categories tasty, innovation, sweet taste, plant flavor, smooth and creamy, and the acceptance index was 74\% (Mazon et al. 2020)

In a study was added addition of microcapsules of pistachio peel extract (MPPE) to produce a functional ice cream, The addition of MPPE to ice cream mixes improved the melting resistance, first dripping times and functional properties of ice cream such as antioxidant activity and total phenolic content. The results of the sensory analysis showed that the addition of MPPE had no significant effect on the overall acceptability of the product (Ghandehari Yazdi et al., 2020).

The banana content of carbohydrates, fats, protein and ash was $22.84,0.33,1.09$ and $0.8 \%$ (Sivalingam et al., 2017).

In a study innovative methods based in consumer perception where was compare the preferred attribute elicitation-PAE methodology ( $n=20$ consumers $)$ with conventional descriptive analysis-DA ( $\mathrm{n}=15$ trained judges) to determine the sensory profile of probiotic yogurts (L. casei) the sensory acceptance obtained using PAE consumers was similar to that obtained with general consumers. PAE methodology can be used to characterize sensorially and to determine the consumers' acceptance of functional yogurts (Costa et al., 2020) .

And in studying on flavor enhancer probiotic prato cheese aimed to combine quantitative descriptive analysis (QDA) and temporal dominancef sensations (TDS) to assess the sensory profile of reduced-sodium probiotic prato cheese with the addition of flavor enhancers, Overall, QDA and TDS used together provided interesting insights for establishing the sensory profile of reduced-sodium probiotic prato cheese (Silva et al., 2018) .

The objective of this study were to show the effect of partial substitution of the sorting milk used in the manufacture of ice cream with dried fruits (bananas, quince, peach and apple).

\section{Materials and methods}

1. Raw cow milk obtained from the Department animal produce / College of Agriculture and Forestry / University of Mosul;

\section{Powdered skim milk Regilait type French origin;}

3. cream fat percentage of $25 \%$ Kuwaiti of origin;

4. Banana, peach, quince, green apple obtained from the local markets where they were washed and cut into slices and dried $\mathrm{On} 50^{\circ} \mathrm{C}$ and then grind; 
5. Installer CMC carboxyl Methyl cellulos brand Akzonobel type 500 Mycell Netherlands origin;

6. Turkish vanilla mark (zer) available in local markets;

7. high purity sugar brand T.S.M Thailand origin;

8. Separator type Aetpo cenapatop Russian origin.

\subsection{Search plan}

The samples were divided into 13 sections:

- M: Sample control Without any replacing

- M1: replacing $10 \%$ banana

- M2: replacing 20\% banana

- M3: replacing 30\% banana

- M4: replacing $10 \%$ peach

- M5: replacing 20\% peach

- M6: replacing 30\% peach

- M7: replacing $10 \%$ quince

- M8: replacing 20\% quince

- M9: replacing 30\% quince

- M10: replacing 10\% apple

- M11: replacing 20\% apple

- M12: replacing 30\% apple

\subsection{Chemical composition of cow milk and Powdered skim milk (Regilait)}

The chemical composition of cow milk was estimated by device Milkoscan As for Powdered skim milk taken from the information on the can, Ash was estimated in the laboratory Table 1.

\subsection{Ice cream preparation}

The ice creams were prepared based on the formulation proposed by Gandolfi \& Muller (2014), with modifications. Formulas of the mixes are shown in Table 2.

\subsection{Chemical estimate}

Total solid, fat, carbohydrate, fiber and Protein for both the fruit used and the resulting ice cream were estimated according to the method described in A.O.A.C. (Association of Official Analytical Chemists, 2010). used to calculate the $\mathrm{pH}$ value of the product Senso Dirct PH200 German origin.

\subsection{Physical analysis}

Determine the specific weight of the product according to the method described in Ling (1963) using a density vial. Relative viscosity in the mixture is calculated as mentioned by Arbuckle (1986). In order to determine the increase in
Table 1. Chemical Composition of Raw cows milk and Milk powder sorting (Regilait).

\begin{tabular}{lcc}
\hline Component \% & Raw cows milk & $\begin{array}{c}\text { Milk powder sorting } \\
\text { (Regilait) }\end{array}$ \\
\hline Total solids & 12.23 & $96-97$ \\
Fat & 3.00 & 0.8 \\
Protein & 3.01 & 35.5 \\
Ash & 0.8 & 7.7 \\
Carbohydrate & 4.6 & 51.7 \\
PH & 6.6 & 6.37 \\
\hline
\end{tabular}

Table 2. Percentages of ingredients involved in the manufacture of a mixture of ice cream in which non-fat solids (powdered Milk skim) are substituted with powder (bananas, peaches, quince, or apples).

\begin{tabular}{lcccc}
\hline \multirow{2}{*}{\multicolumn{1}{c}{ Subject }} & control & \multicolumn{3}{c}{$\begin{array}{c}\text { Substitution rates kg / 100kg ice } \\
\text { cream mixture }\end{array}$} \\
\cline { 3 - 5 } & sample & $10 \%$ & $20 \%$ & $30 \%$ \\
\hline Sugar & 15 & 15 & 15 & 15 \\
Substitution & 0 & 0.53 & 1.06 & 1.59 \\
powdered Milk skim & 5.3 & 4.77 & 4.24 & 3.71 \\
Cream 25\% fat & 8 & 8 & 8 & 8 \\
Vanilla & 0.1 & 0.1 & 0.1 & 0.1 \\
Installer & 0.3 & 0.3 & 0.3 & 0.3 \\
Fresh cow's milk & 71.3 & 71.3 & 71.3 & 71.3 \\
\hline
\end{tabular}

volume of ice-cream with respect to that of ice-cream mix, the overrun values were determined and calculated on a weight basis using the formula described by Muse \& Hartel (2004): overrun $=[(W 1-W 2) / W 2] x 100$, where $\mathrm{W} 1=$ weight of $250 \mathrm{~mL}$ of the mix and $\mathrm{W} 2=$ weight of $250 \mathrm{~mL}$ of ice cream.

\subsection{Organoleptic properties}

The product was evaluated by a number of specialists in the Department of Food Science and Biotechnology/College of Agriculture and Forestry / University of Mosul. Sensory assessment scores were given as suggested by Salim (1986).

\subsection{Microbial tests}

The total number of bacteria, yeasts, molds and coliform bacteria were estimated as reported in American Public Health Association (1987).

\subsection{Statistical analysis}

The statistical analysis for the obtained data were done according to the SAS Version Statistical Analysis System (SAS Institute Inc., 2001)., Differences were considered significant at $\mathrm{P} \leq 0.05$. Significant variations were determined by Duncan's multiple range test Duncan (1955). 


\section{Results and discussion}

\subsection{The chemical composition of fruits used in the study:}

The data in (Table 3 ) showed the chemical composition of the fruits used in manufacturing the blends of ice cream, total solids rate was the highest in banana fruit, reaching 27.4 , this is probably due to the high banana content of carbohydrates, protein and ash, these results were close to the results obtained by Sivalingam et al. (2017). While the lowest rate was in peach fruit, reaching 14.7 due to the low content of carbohydrates, protein and ash. The fat rate was equal for all fruits, except in banana fruit the fats, protein and ash rates were high as compared to other fruits, As for fiber, quince contained the highest rate compared to other fruits, reached $2.2 \%$.

\subsection{The chemical composition of the resultant ice cream}

The results in (Table 4) show the chemical composition of ice cream components, the total solids rate was $29.59 \%$ in control, the use of dried banana powder, at replacement rate $10 \%$ instead of dried skim milk powder increase the total solids rate slightly in resultant ice cream, this value increased with the increasing the proportion of banana powder which may be due to the highest rate of total solids in bananas as compared to other used fruits, and the highest rate reached 30,69 in the treatment M4, while the use of dried peach powder instead of dried skim milk powder, which contains the lowest rate of total solids reduced the rate of total solids in the ice cream as compared to the control, the same result was also obtained by Awad (2007), who indicated that the use of rice flour instead of dried skim milk powder increased the rate of total solids, also agreed with Hasan \& Elias (2013), they indicated that the rate of total solids in the ice cream increased with increasing of replacement rate

By using oatmeal, corn and barley flour instead of dried skim milk powder. The rate of carbohydrates achieved the highest value 10.10 .

In the treatments that used dried banana powder instead of skim milk powder, because of the high content of carbohydrates in bananas, while the carbohydrates rate decreased in the treatments in which dried peaches and apples were used instead of skim milk, due to the low rate of carbohydrates content in previously mentioned fruits. The ash rate was high, $0.998 \%$. in control sample, the addition of dried banana powder did not affect the rate, while peach, quince and apple powder reduced the ash content in the treatments at varying degrees, this is due to the low ash content in this fruits. This results were consistent with the finding of Awad (2007), who find that the ash content decreased in ice cream samples that manufactured by adding rice flour replaces the dried skim milk powder with the increasing in the replacement rate, as well as agreed with Hasan \& Elias (2013), they indicated that the ash content decreased in ice cream samples that manufactured by adding oatmeal, corn and barley flour instead of dried skim milk powder with increasing of replacement rate due to the high skim milk content of mineral elements.
Table 3. Chemical composition of fruits used as substitutes for sorting milk before drying.

\begin{tabular}{lrrrc}
\hline \multicolumn{1}{c}{ \% Component } & Banana & Peache & Quince & Apple \\
\hline Total solids & $27.4^{\mathrm{a}}$ & $14.7^{\mathrm{c}}$ & $20.1^{\mathrm{b}}$ & $16.1^{\mathrm{bc}}$ \\
Fat & $0.2^{\mathrm{a}}$ & $0.2^{\mathrm{a}}$ & $0.3^{\mathrm{a}}$ & $0.3^{\mathrm{a}}$ \\
Protein & $1.5^{\mathrm{a}}$ & $0.8^{\mathrm{b}}$ & $0.6^{\mathrm{bc}}$ & $0.3^{\mathrm{c}}$ \\
Ash & $1.1^{\mathrm{a}}$ & $0.4^{\mathrm{c}}$ & $0.4^{\mathrm{c}}$ & $0.8^{\mathrm{b}}$ \\
Fiber & $0.5^{\mathrm{b}}$ & $0.9^{\mathrm{b}}$ & $2.2^{\mathrm{a}}$ & $0.7^{\mathrm{b}}$ \\
Carbohydrate & $24.1^{\mathrm{a}}$ & $12.4^{\mathrm{c}}$ & $16.8^{\mathrm{b}}$ & $14^{\mathrm{bc}}$ \\
\hline
\end{tabular}

The characters indicated significant differences between the coefficients within a row $(\mathrm{P}<0.05)$.

Table 4. The chemical composition of the resulting ice cream.

\begin{tabular}{ccccl}
\hline Treatment & Total solids & Carbohydrate & Ash & PH \\
\hline M & $29.59^{\mathrm{b}}$ & $8.98^{\mathrm{b}}$ & $0.998^{\mathrm{a}}$ & $6.42^{\mathrm{a}}$ \\
M1 & $29.79^{\mathrm{ab}}$ & $9.23^{\mathrm{ab}}$ & $0.998^{\mathrm{a}}$ & $4.48^{\mathrm{c}}$ \\
M2 & $29.99^{\mathrm{ab}}$ & $9.48^{\mathrm{ab}}$ & $0.996^{\mathrm{a}}$ & $4.48^{\mathrm{c}}$ \\
M3 & $30.69^{\mathrm{a}}$ & $10.10^{\mathrm{a}}$ & $0.994^{\mathrm{a}}$ & $4.44^{\mathrm{c}}$ \\
M4 & $27.68^{\mathrm{d}}$ & $7.03^{\mathrm{d}}$ & $0.839^{\mathrm{b}}$ & $5.34^{\mathrm{b}}$ \\
M5 & $28.08^{\mathrm{cd}}$ & $8.43^{\mathrm{c}}$ & $0.817^{\mathrm{b}}$ & $5.32^{\mathrm{b}}$ \\
M6 & $28.58^{\mathrm{c}}$ & $7.96^{\mathrm{cd}}$ & $0.797^{\mathrm{c}}$ & $5.32^{\mathrm{b}}$ \\
M7 & $29.50^{\mathrm{b}}$ & $8.92^{\mathrm{b}}$ & $0.841^{\mathrm{b}}$ & $4.48^{\mathrm{c}}$ \\
M8 & $29.69^{\mathrm{b}}$ & $9.03^{\mathrm{b}}$ & $0.817^{\mathrm{b}}$ & $4.46^{\mathrm{c}}$ \\
M9 & $30.00^{\mathrm{ab}}$ & $9.45^{\mathrm{ab}}$ & $0.785^{\mathrm{c}}$ & $4.46^{\mathrm{c}}$ \\
M10 & $28.26^{\mathrm{c}}$ & $7.52^{\mathrm{d}}$ & $0.926^{\mathrm{b}}$ & $6.45^{\mathrm{a}}$ \\
M11 & $28.74^{\mathrm{c}}$ & $8.01^{\mathrm{cd}}$ & $0.918^{\mathrm{b}}$ & $6.45^{\mathrm{a}}$ \\
M12 & $29.04^{\mathrm{b}}$ & $8.39^{\mathrm{c}}$ & $0.906^{\mathrm{b}}$ & $6.48^{\mathrm{a}}$ \\
\hline
\end{tabular}

The characters indicated significant differences between the coefficients within a column ( $\mathrm{P}<0.05)$. M: Sample control Without any replacing, M1: replacing 10\% banana; M2: replacing $20 \%$ banana; M3: replacing 30\% banana ; M4: replacing $10 \%$ peach; M5: replacing $20 \%$ peach; M6: replacing $30 \%$ peach; M7: replacing $10 \%$ quince; M8: replacing $20 \%$ quince ; M9: replacing 30\% quince ; M10: replacing 10\% apple ; M11: replacing $20 \%$ apple ; M12: replacing $30 \%$ apple.

The data in (Table 4) also show $\mathrm{pH}$ values of resultant ice cream which was 6.42 in the control sample, this value is high as compared with the $\mathrm{pH}$ of other ice cream samples, except the $\mathrm{pH}$ of ice cream samples made by adding dried apple powder instead of skim milk powder which was 6.45 at $10 \%$, then increased to reach 6.48 at $30 \%$ replacement rate due to the low acidity of adding apple powder .This results were in agreement with the findings of Hayakawa \& Nakai (1985) who reported that the soybean proteins affect the net charge on the protein molecule and then affect the $\mathrm{pH}$ values of the product due to the emulsification of the fat with the protein which leads to a decrease in acidity, as well as agreed with Hasan \& Elias (2013), they indicated that the $\mathrm{pH}$ values increased slightly with the increasing the proportion of some cereals flour in the blend of flour - skim milk. These results also were in agreement with Mahdian et al (2012), who reported that the $\mathrm{pH}$ values reduced in the treatments that used soybean flour instead of skim milk powder, from 5.3 to $47.4 \%$, and the decreasing continued with 
an increase in the replacement rate, due to the increased acidity from soybean milk, while these results did not agree with Akesowan (2009) who indicated an increase in the $\mathrm{pH}$ value of the ice cream samples manufactured with soybean protein instead of dried skim milk with replacement rates of 25, 50, 75. $100 \%$ from 6.22 at $25 \%$ to 6.34 at $100 \%$ replacement.

\subsection{Physical characteristics of the resultant ice creams:}

In (Table 5) are presented the data of the physical characteristics, relative viscosity and yield rate of the resultant ice cream samples from replace the skim milk powder with fruits powder, the specific weight of the control sample was 0.959 , the specific weight values tended to increase with increasing the proportion of fruit powders in most treatments, due to the increase in the total solids in ice cream samples, the highest specific weight values were in the ice cream samples prepared from blends of dried banana - skim milk powder which was 1.166 at $10 \%$ replacement rate and reached 1.391 and 1.528 at $20 \%$ and $30 \%$ replacement rate respectively, the relative viscosity was 8.74 at control sample, the viscosity of ice cream mixes gradually increased with increasing the proportion of fruits powder in the blend, there was directly proportional between replacement rate and relative viscosity, we found that the ice cream samples with a high specific weight had the highest relative viscosity, as in ice cream samples made by adding dried banana powder with skim milk powder, the highest values of the relative viscosity, was 9.52 at $10 \%$ replacement rate and reached 13.92 at 30\% replacement rate, the yield rate recorded the highest value in the control sample,

However, this value decreased in all other treatments, as well as the samples with a high viscosity value record low value of yield rate, which mean there is an inverse relationship between replacement rate and yield rate, this is due to the prevention of air entering the ice cream mixture during the whipping process due to the increase in the relative viscosity, as in the samples made by adding dried banana powder instead of dried skim milk powder alone which was $64.3 \%$ at $10 \%$ replacement rate, and became $62.8 \%$ at $30 \%$ replacement rate, the samples with low relative viscosity such as ice cream samples made with dried peach powder record highest value of yield rate which was $68.3 \%$ at $10 \%$ replacement rate and decline to $66.9 \%$ at $30 \%$ replacement rate. These results are in agree with Khalil \& Embaby (2012), Awad (2007), Salama \& Azzam (2003), Mahdian et al. (2012) and Akesowan (2009).

\subsection{Microbiological evaluation}

The results in Table 6 shows the microbiological evaluation regarding with ice cream sample that made with dried fruit powder instead of dried skim milk powder alone, the ice cream samples made by replacing dried skim milk powder with dried banana powder contained more bacteria than all other treatments, the total number of bacteria, increased with increasing the proportion of dried fruit powder and this is may be due to the increase in adding fruit powder is an additional factor to increase the number of bacteria as compared to dried skim milk, also may be result from contamination during the manufacturing process and inappropriate conditions of cooling,
Table 5. he physical properties of the resulting ice cream.

\begin{tabular}{cccc}
\hline Treatment & Specific weight & Viscosity & Yield \\
\hline M & $0.959^{\mathrm{d}}$ & $8.74^{\mathrm{c}}$ & $70.2^{\mathrm{a}}$ \\
M1 & $1.166^{\mathrm{b}}$ & $9.52^{\mathrm{b}}$ & $64.3^{\mathrm{b}}$ \\
M2 & $1.391^{\mathrm{ab}}$ & $10.71^{\mathrm{ab}}$ & $63.5^{\mathrm{d}}$ \\
M3 & $1.528^{\mathrm{a}}$ & $13.92^{\mathrm{a}}$ & $62.8^{\mathrm{d}}$ \\
M4 & $0.939^{\mathrm{d}}$ & $8.52^{\mathrm{c}}$ & $68.3^{\mathrm{b}}$ \\
M5 & $0.970^{\mathrm{cd}}$ & $8.65^{\mathrm{c}}$ & $67.8^{\mathrm{b}}$ \\
M6 & $1.049^{\mathrm{c}}$ & $8.32^{\mathrm{c}}$ & $66.9^{\mathrm{b}}$ \\
M7 & $1.072^{\mathrm{c}}$ & $8.12^{\mathrm{c}}$ & $66.2^{\mathrm{b}}$ \\
M8 & $1.147^{\mathrm{b}}$ & $9.11^{\mathrm{b}}$ & $65.9^{\mathrm{bc}}$ \\
M9 & $1.357^{\mathrm{ab}}$ & $10.96^{\mathrm{ab}}$ & $65.2^{\mathrm{c}}$ \\
M10 & $1.017^{\mathrm{c}}$ & $8.18^{\mathrm{c}}$ & $67.9^{\mathrm{b}}$ \\
M11 & $1.084^{\mathrm{bc}}$ & $8.97^{\mathrm{bc}}$ & $66.4^{\mathrm{b}}$ \\
M12 & $1.108^{\mathrm{bc}}$ & $10.07^{\mathrm{ab}}$ & $65.8^{\mathrm{bc}}$ \\
\hline
\end{tabular}

The characters indicated significant differences between the coefficients within a column $(\mathrm{P}<0.05)$. M: Sample control Without any replacing, M1: replacing $10 \%$ banana; $\mathrm{M} 2$ : replacing $20 \%$ banana; M3: replacing $30 \%$ banana ; M4: replacing $10 \%$ peach; M5: replacing $20 \%$ peach; M6: replacing $30 \%$ peach ; M7: replacing $10 \%$ quince; M8: replacing $20 \%$ quince; M9: replacing $30 \%$ quince; M10: replacing $10 \%$ apple; M1 1: replacing $20 \%$ apple ; M12: replacing $30 \%$ apple.

Table 6. Preparing microorganisms in the added ice cream with alternatives for sorting milk.

\begin{tabular}{crrr}
\hline Treatment & Total bacteria & $\begin{array}{r}\text { coliform } \\
\text { bacteria }\end{array}$ & $\begin{array}{c}\text { Yeasts and } \\
\text { molds }\end{array}$ \\
\hline M & $17 \times{ }^{3} 10^{\mathrm{c}}$ & $23 \times{ }^{1} 10^{\mathrm{a}}$ & $9 \times{ }^{2} 10^{\mathrm{c}}$ \\
M1 & $140 \times{ }^{3} 10^{\mathrm{b}}$ & $1 \times{ }^{1} 10^{\mathrm{b}}$ & $14 \times{ }^{2} 10^{\mathrm{bc}}$ \\
M2 & $197 \times{ }^{3} 10^{\mathrm{a}}$ & $2 \times{ }^{1} 10^{\mathrm{b}}$ & $34 \times{ }^{2} 10^{\mathrm{b}}$ \\
M3 & $280 \times{ }^{3} 10^{\mathrm{a}}$ & $2 \times{ }^{1} 10^{\mathrm{b}}$ & $80 \times{ }^{2} 10^{\mathrm{a}}$ \\
M4 & $6 \times{ }^{3} 10^{\mathrm{c}}$ & $5 \times{ }^{1} 10^{\mathrm{b}}$ & $25 \times{ }^{2} 10^{\mathrm{b}}$ \\
M5 & $9 \times{ }^{3} 10^{\mathrm{c}}$ & $4 \times{ }^{1} 10^{\mathrm{b}}$ & $18 \times{ }^{2} 10^{\mathrm{bc}}$ \\
M6 & $60 \times{ }^{3} 10^{\mathrm{bc}}$ & $2 \times{ }^{1} 10^{\mathrm{b}}$ & $16 \times{ }^{2} 10^{\mathrm{bc}}$ \\
M7 & $2 \times{ }^{3} 10^{\mathrm{c}}$ & $1 \times{ }^{1} 10^{\mathrm{b}}$ & $14 \times{ }^{2} 10^{\mathrm{bc}}$ \\
M8 & $20 \times{ }^{3} 10^{\mathrm{c}}$ & $7 \times{ }^{1} 10^{\mathrm{b}}$ & $9 \times{ }^{2} 10^{\mathrm{c}}$ \\
M9 & $24 \times{ }^{3} 10^{\mathrm{c}}$ & $9 \times{ }^{1} 10^{\mathrm{b}}$ & $2 \times{ }^{2} 10^{\mathrm{c}}$ \\
M10 & $8 \times{ }^{3} 10^{\mathrm{c}}$ & $15 \times{ }^{1} 10^{\mathrm{ab}}$ & $1 \times{ }^{2} 10^{\mathrm{c}}$ \\
M11 & $7 \times{ }^{3} 10^{\mathrm{c}}$ & $12 \times{ }^{1} 10^{\mathrm{ab}}$ & $10 \times{ }^{2} 10^{\mathrm{c}}$ \\
M12 & $10 \times{ }^{3} 10^{\mathrm{c}}$ & $8 \times{ }^{1} 10^{\mathrm{b}}$ & $13 \times{ }^{2} 10^{\mathrm{bc}}$ \\
\hline
\end{tabular}

The characters indicated significant differences between the coefficients within a column ( $\mathrm{P}<0.05)$. M: Sample control Without any replacing, M1: replacing $10 \%$ banana; M2: replacing 20\% banana; M3: replacing 30\% banana ; M4: replacing $10 \%$ peach; M5: replacing $20 \%$ peach; M6: replacing $30 \%$ peach; M7: replacing $10 \%$ quince; M8: replacing $20 \%$ quince ; M9: replacing $30 \%$ quince ; M10: replacing $10 \%$ apple ; M11: replacing $20 \%$ apple ; M12: replacing $30 \%$ apple.

which leads to an increasing in the number of bacteria quickly due to the slow cooling after the pasteurization when the temperature is appropriate to form spores, the range of total bacterial count for ice cream samples was between $140 \times 10^{3}$ at $10 \%$ and $280 \times 10^{3}$ at $30 \%$ replacement rate, these results agree 
with Ojokoh (2006) who indicated that the total number of bacteria range between $6.8 \times 103$ to $1.28 \times 104$ in ice cream samples collected from local shops, our results also agree with Supavititpattana \& Kongbangkerd (2011) who indicated to the increasing in total number of microorganisms in Yogurt-ice cream samples manufactured from coconut milk in which the non-fatty solids have been partially replaced by sodium casein and the total number of microorganisms rise with the increase in the replacement rate to $14 \%$ non-fat solids and $1 \%$ sodium casein due to the presence of amino acids originating from sodium caseins that encourage the bacteria growth.

The count of E.coli bacteria for all treatments except the control sample was within the permissible limit according to Iraqi specifications which is less than $10 \mathrm{cfu} / \mathrm{mL}$, except ice cream samples made by replace $10 \%$ and $20 \%$ of skim milk with dried peach powder the count of bacteria was 15 and $12 \mathrm{cfu} / \mathrm{mL}$ respectively, these results agree with Hasan \& Elias (2013), they found that the count of E. coli was Less than $10 \mathrm{cfu} / \mathrm{mL}$, And that this bacteria was present because of the inefficiency of the pasteurization process or because of manual contamination. While the count of yeasts and molds ranged between $1 \times 10^{2}$ in the sample of ice cream made with peaches at $30 \%$ to $80 \times 10^{2}$ in the sample of ice cream made with dried banana powder at $30 \%$ instead of dried skim milk powder and there is an increase in the number of yeasts and molds with an increase in the replacement rate.

\subsection{Sensory characteristics evaluation}

The data in Table 7 shown the points of ice cream samples which made by replacing skim milk with different types of dried fruits powder, the results indicated that these samples record high points for flavor which was 45 points in control sample and 46 in samples which made by replacing skim milk with dried banana and apple powder, also the flavor points rised with replacement rate increasing due to add the fruit flavor. The control and the samples made with apple powder at proportion $10 \%$ achieved the highest values of body and texture which were 26 points, and slightly decreased with the increase in the proportion rate because of the roughness of texture and being granular, these results are agreed with El-Samahy et al. (2009) who find the addition of prickly pear pulp to the ice-cream mixture in the proportions of 5, 10 and $15 \%$ it has led to an improvement in the body and texture at the rate of addition 5\%, then this points decline with an increase in the rate of addition while it did not agreed with Supavititpattana \& Kongbangkerd (2011) Which indicated an increase in texture and body points due to the increase in addition of sodium casein as a partial substitute non-fatty solids to yogurt-ice cream has led to an increase in hardness due to the action of sodium casein as an emulsion which increases the strength of bonding between the different parts and increases the strength of the network of yogurt-ice cream.

The control ice cream sample had the maximum ( 9 points) for colour, and decreased with the increasing in the proportion of fruit powder due to the appearance of a grainy and dark color, these results agreed with Akesowan (2009) which indicated a decrease in the color points of the ice cream samples due to the increase in the degree of opacity with the increase in the
Table 7. The degrees of the sensory evaluation of the added ice cream samples, with alternatives to sorting milk.

\begin{tabular}{ccccc}
\hline Treatment & $\begin{array}{c}\text { The taste is } \\
\text { 50 degrees }\end{array}$ & $\begin{array}{c}\text { Textures and } \\
\text { composition } \\
\text { 30 degrees }\end{array}$ & $\begin{array}{c}\text { Color 10 } \\
\text { degrees }\end{array}$ & $\begin{array}{c}\text { External } \\
\text { appearance } \\
\text { 10 degrees }\end{array}$ \\
\hline M & 45 & 26 & 9 & 8 \\
M1 & 46 & 25 & 8 & 8 \\
M2 & 47 & 24 & 8 & 9 \\
M3 & 49 & 24 & 7 & 10 \\
M4 & 45 & 24 & 8 & 8 \\
M5 & 46 & 24 & 7 & 7 \\
M6 & 46 & 23 & 6 & 7 \\
M7 & 44 & 22 & 7 & 6 \\
M8 & 46 & 22 & 7 & 6 \\
M9 & 47 & 23 & 6 & 5 \\
M10 & 46 & 26 & 8 & 8 \\
M11 & 46 & 24 & 8 & 8 \\
M12 & 48 & 24 & 6 & 7 \\
\hline
\end{tabular}

The characters indicated significant differences between the coefficients within a column $(\mathrm{P}<0.05) . \mathrm{M}$ : Sample control Without any replacing, M1: replacing $10 \%$ banana; M2: replacing $20 \%$ banana; M3: replacing $30 \%$ banana ; M4: replacing $10 \%$ peach; M5: replacing 20\% peach; M6: replacing 30\% peach ; M7: replacing 10\% quince; M8: replacing $20 \%$ quince ; M9: replacing 30\% quince; M10: replacing $10 \%$ apple ; M11: replacing $20 \%$ apple ; M12: replacing 30\% apple.

proportion of soybean protein also we agreed with Supavititpattana \& Kongbangkerd (2011) they indicated that the increase in the addition of sodium casein as a partial substitute to non-fat solids to the yogurt-ice cream has led to a decrease in color points due to the increase in color fading with the increase in the replacement rate. The same applies to the appearance points of the ice cream samples except a slight improvement in the sample of ice cream made with banana powder which was 8 and become 10 at $10 \%$ and $30 \%$ replacement rate respectively.

\section{Conclusion}

The ice cream obtained from replacing the fruit extracts with the dried sorting milk led to an increase in the percentage of the total solids, an increase in viscosity, and an improvement in the sensory properties of the ice cream. it is suggested further studies on the replacement of low-energy products in the ice cream industry

\section{Acknowledgements}

Thanks to all the staff of the Dairy Lab., Food Science Department, the University of Mosul for their financial support.

\section{References}

Acu, M., Kinik, O., \& Yerlikaya, O. (2020). Probiotic viability, viscosity, hardness properties and sensorial quality of synbiotic ice creams produced from goat's milk. Food Science and Technology. In press. https://doi.org/10.1590/fst.39419. 
Akesowan, A. (2009). Influence of soy protein Isolate on physical and sensory properties of Ice cream. Thai Journal of Agricultural Science, 42(1), 1-6.

Al-Rubaie, D. J. (2013). The Arab Encyclopedia of Medicinal Herbs Therapy. Beirut: House of revival of Arab Heritage.

American Public Health Association - APHA. (1987). Standard methods for the examination of dairy products (14th ed.). Washington: APHA.

Arbuckle, W. S. (1986). Ice cream (4th ed., xiii+483 p.). Westport: AVI Publishing Co.

Association of Official Analytical Chemists - AOAC. (2010). Official methods of analysis of the Association of Official Analytical Chemists. Washington: AOAC.

Awad, R. A. (2007). Performance of rice flour in ice cream manufactre. In Proceedings of the Conference of Dairy Science \& Technology (pp. 517-534). Cairo: Egyptian Society of Dairy Science.

Balthazar, C. F., Silva, H. L., Celeguini, R. M., Santos, R., Pastore, G. M., Conte, C. A. Jr., Freitas, M. Q., Nogueira, L. C., Silva, M. C., \& Cruz, A. G. (2015). Effect of galactooligosaccharide addition on the physical, optical, and sensory acceptance of vanilla ice cream. Journal of Dairy Science, 98(7), 4266-4272. http://dx.doi.org/10.3168/ jds.2014-9018. PMid:25912870.

Balthazar, C.F., Silva, H. L. A., Esmerino, E. A., Rocha, R. S., Moraes, J., Carmo, M. A. V., Azevedo, L., Camps, I., Abud, Y. K. D., Sant'Anna, C., Franco, R. M., Freitas, M. Q., Silva, M. C., Raices, R. S. L., Escher, G. B., Granato, D., Ranadheera, C. S., Nazzaro, F., Cruz, A. G. (2018). The addition of inulin and Lactobacillus casei 01 in sheep milk ice cream. Food Chemistry, 246, 464-472. http://dx.doi.org/10.1016/j. foodchem.2018.01.186. PMID: 29478559.

Clarke, C. (2005). The science of ice cream. Cambridge: The Royal Society of Chemistry.

Costa, G. M., Paula, M. M., Costa, G. N., Esmerino E. A., Silva, R., Freitas, M. Q., Barão, C. E., Cruz, A. G., Pimentel, T. C. (2020). Preferred attribute elicitation methodology compared to conventional descriptive analysis: a study using probiotic yogurt sweetened with xylitol and added with prebiotic components. Journal of Sensory Studies, e12602. https://doi.org/10.1111/joss.12602.

Cruz, A. G., Antunes, A. E., Sousa, A. L. O., Faria, J. A., \& Saad, S. M. (2009). Ice-cream as a probiotic food carrier. Food Research International, 42(9), 1233-1239. http://dx.doi.org/10.1016/j.foodres.2009.03.020.

Duncan, D. B. (1955). Multiple range and multiple F test biometric. Journal Storage, 11(1), 1-42. http://dx.doi.org/10.2307/3001478.

El-Samahy, S. K., Youssef, K. M., \& Mossa-Ayoub, T. E. (2009). Producing ice cream with concentrated cactus pear pulp. Journal of the Professional Association for Cactus Development, 11, 1-12.

Ferraz, J. L., Cruz, A. G., Cadena, R. S., Freitas, M. Q., Pinto, U. M., Carvalho, J. A. F., \& Bolini, H. M. A. (2012). Sensory acceptance and survival of probiotic bacteria in ice cream produced with different overrun levels. Journal of Food Science, 77(1), S24-S28. http://dx.doi. org/10.1111/j.1750-3841.2011.02508.x. PMid:22260128.

Gandolfi, M. A. C., \& Muller, T. P. (2014). Elaboração de sorvete adicionado de chia e mel (Course completion assignment). Universidade Tecnológica Federal do Paraná, Francisco Beltrão.

Ghandehari Yazdi, A. P., Barzegar, M., Ahmadi Gavlighi, H., Sahari, M. A., \& Mohammadian, A. H. (2020). Physicochemical properties and organoleptic aspects of ice cream enriched with microencapsulated pistachio peel extract. International Journal of Dairy Technology, 73(3), 570-577. http://dx.doi.org/10.1111/1471-0307.12698.

Goff, H. D., \& Hartel, R. W. (2013). Ice cream (7th ed.). New York: Springer Sci. Business Media. http://dx.doi.org/10.1007/978-1-4614-6096-1.
Hasan, G. M., \& Elias, S. M. (2013). Use flour types of grain as areplacement for material non fat solid in ice milk (Master's thesis). College of Agriculture and Forestry, University of Mosul, Mosul.

Hassan, M. F. Y., \& Barakat, H. (2018). Effect of carrot and pumpkin pulps adding on chemical, rheological, nutritional and organoleptic properties of ice cream. Food and Nutrition Sciences, 9(08), 969-982. http://dx.doi.org/10.4236/fns.2018.98071.

Hayakawa, S., \& Nakai, S. (1985). Relationships of hydrophrobicity and net charge to solubitity of milk and soyprotein. Journal of Food Science, 50(2), 486-491. http://dx.doi.org/10.1111/j.1365-2621.1985. tb13433.x.

Januário, J. G. B., Oliveira, A. S., Dias, S. S., Klososki, S. J., \& Pimentel, T. C. (2018). Kefir ice cream flavored with fruits and sweetened with honey: physical and chemical characteristics and acceptance. International Food Research Journal, 25(1), 179-187.

Karaman, S., Toker, Ö. S., Yüksel, F., Çam, M., Kayacier, A., \& Dogan, M. (2014). Physicochemical, bioactive, and sensory properties of persimmon-based ice cream: Technique for order preference by similarity to ideal solution to determine optimum concentration. Journal of Dairy Science, 97(1), 97-110. http://dx.doi.org/10.3168/ jds.2013-7111. PMid:24268400.

Khalil, R. A. M., \& Embaby, H. E. (2012). The use of Jambul fruit (Syzygium cumini) as asourse of natural anti oxidant in functional low fat ice cream making. Egyptian Journal of Dairy Science, 40, 75-84.

Ling, E. R. (1963). Text book of dairy chemistry (3rd ed., Vol. 2). London: Chapman of Hall Ltd.

Mahdian, E., Mazaheri Tahrani, M., \& Nobahari, M. (2012). Optimizing yoghurt ice cream mix blend in soy based frozen yoghurt. Journal of Agricultural Science and Technology, 14(6), 1275-1284.

Mazon, S., Menin, D., Cella, B. M., Lise, C. C., Vargas, T. de O., \& Daltoé, M. L. M. (2020). Exploring consumers' knowledge and perceptions of unconventional food plants: case study of addition of pereskia aculeata miller to ice cream. Food Science and Technology (Campinas), 40(1), 215-221. http://dx.doi.org/10.1590/fst.39218.

Muse, M. R., \& Hartel, R. W. (2004). Ice cream structural elements that affect melting rate and hardness. Journal of Dairy Science, 87(1), 1-10. http://dx.doi.org/10.3168/jds.S0022-0302(04)73135-5. PMid:14765804.

Ojokoh, A. O. (2006). Microbiological examination of ice cream sold in Akure. Pakistan Journal of Nutrition, 5(6), 536-538. http://dx.doi. org/10.3923/pjn.2006.536.538.

Ozdemir, C., Dagdemir, E., Ozdemir, S., \& Sagdic, O. (2008). The effects of using alternative sweeteners to sucrose on ice cream quality. Journal of Food Quality, 31(4), 415-428. http://dx.doi.org/10.1111/j.17454557.2008.00209.x.

Salama, F. M. M., \& Azzam, M. A. A. (2003). The use of wheat germ in the manufacture of ice milk. Egyptian Journal of Dairy Science, 31(2), 389-398.

Salim, R. M. (1986). Milky ice cream, house of books for printing and publishing. Mosul: Mosul University.

SAS Institute Inc. (2001). SAS version statistical analysis system. Cary: SAS Institute Inc.

Silva, H. L. A., Balthazar, C. F., Silva, R., Vieira, A. H., Costa, R. G. B., Esmerino, E. A., Freitas, M. Q., \& Cruz, A. G. (2018). Sodium reduction and flavor enhancer addition in probiotic prato cheese: contributions of quantitative descriptive analysis and temporal dominance of sensations for sensory profiling. Journal of Dairy Science, 101(10), 8837-8846. http://dx.doi.org/10.3168/jds.201814819. PMid:30077456. 
Sivalingam, E., Sreeramanan, S., Shobana, V. G., \& Ashok, K. (2017). An overview on phytochemical composition of banana. Indian Journal of Natural Sciences., 7(42), 12408-12419.

Sukumar, D. (1980). Outlines of dairy technology. England: Oxford University Press.

Sun-Waterhouse, D. (2011). The development of fruit-based functional foods targeting the health and wellness market: a review. International Journal of Food Science \& Technology, 46(5), 899-920. http://dx.doi. org/10.1111/j.1365-2621.2010.02499.x.

Supavititpattana, P., \& Kongbangkerd, T. (2011). The effect of partial replacement of non-fat milk with Sodium caseinate on qualities of yogurt ice cream from coconut milk. International Food Research Journal, 18(1), 439-443.
Torres, F. R., Silva, H. L. A., Cutrim, C. S., \& Cortez, M. A. S. (2020). Consumer perception of Petit-Suisse cheese: identifying market opportunities for the Brazilian dairy industry. Food Science and Technology. In press. http://orcid.org/0000-0003-4546-5891.

Villalva, F. J., Cravero Bruneri, A. P., Vinderola, G., Gonçalvez de Oliveira, E., Paz, N. F., \& Ramón, A. N. (2017). Formulation of a peach ice cream as potential symbiotic food. Food Science and Technology (Campinas), 37(3), 456-461. http://dx.doi.org/10.1590/1678-457x.19716.

Vital, A. C. P., Santos, N. W., Matumoto-Pintro, P. T., Silva Scapim, M. R., \& Madrona, G. S. (2018). Ice cream supplemented with grape juice residue as a source of antioxidants. International Journal of Dairy Technology, 71(1), 183-189. http://dx.doi.org/10.1111/14710307.12412. 